\title{
Makna Pendidikan Formal dan Ajaran Samin di Desa Sambongrejo Kecamatan Sambong Kabupaten Blora
}

\author{
Rohana Siti Nurkasanah ${ }^{1}$, Agus Purnomo², Bayu Kurniawan ${ }^{3}$ \\ Program Studi Pendidikan IPS Fakultas IImu Sosial Universitas Negeri Malang ${ }^{1,2,3}$ \\ Email : agus.purnomo.fis@um.ac.id²*

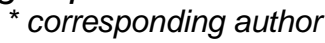

\begin{abstract}
Abstrak
Masyarakat Samin adalah salah satu komunitas di Jawa Tengah yang biasa dikenal dengan sedulur sikep. Masyarakat Samin muncul sebagai bentuk penolakan terhadap Belanda. Penolakan tersebut diikuti dengan sikap tidak setuju terhadap beberapa hal, misalnya keberadaan sekolah. Akan tetapi, perkembangan zaman yang semakin maju telah membawa banyak perubahan pada masyarakat Samin. Tujuan penelitian ini untuk mendeskripsikan sejarah, makna pendidikan formal, dan ajaran Samin. Penelitian ini menggunakan penelitian kualitatif dengan pendekatan deskriptif. Penelitian dilakukan di Desa Sambongrejo Kecamatan Sambong Kabupaten Blora. Data diperoleh dari data primer dan sekunder. Teknik pengumpulan data menggunakan observasi, wawancara, dan dokumentasi. Berdasarkan penelitian dapat disimpulkan bahwa ajaran Samin yang dipelopori Samin Surosentiko pada tahun 1890 dan langsung diterima oleh masyarakat Blora. Hal tersebut dikarenakan keadaan masyarakat Blora sangat memprihatinkan. Tekanan dari pemerintahan Belanda pada bidang pendidikan, melalui sekolah masyarakat akan mendapat penanaman nilai yang berbasis kebudayaan Belanda. Sekitar tahun 1945 setelah Indonesia merdeka, sedikit demi sedikit masyarakat Samin mulai menerima pendidikan formal. Mulai tahun 2000-an mayoritas masyarakat Samin sudah menempuh pendidikan formal sekolah dasar dan sekolah menengah pertama. Ajaran Samin yang masih dipegang teguh sebagai patokan hidup masyarakat Samin yaitu ucapan, pikiran, dan tingkah laku.
\end{abstract}

Kata kunci : pendidikan formal; ajaran hidup; masyarakat Samin

\section{The Meaning of Formal Education and Samin Teachings in Sambongrejo Village, Sambong District, Blora Regency}

\begin{abstract}
The Samin community is a community in Central Java which is commonly known as sedulur sikep. The Samin community emerged as a form of rejection of the Dutch. This rejection was followed by disagreement with several things, for example the existence of a school. However, the progress of the times has brought many changes to the Samin community. The purpose of this study was to describe the history, meaning of formal education, and Samin's teachings. This research uses qualitative research with a descriptive approach. The research was conducted in Sambongrejo Village, Sambong District, Blora Regency. Data obtained from primary and secondary data. Data collection techniques using observation, interviews, and documentation. Based on the research, it can be concluded that the Samin teachings were pioneered by Samin Surosentiko in 1890 and were immediately accepted by the people of Blora. This is because the condition of the people of Blora is very apprehensive. The pressure from the Dutch government on education, through community schools, will get the inculcation of values based on Dutch culture. Around 1945 after Indonesia's independence, little by little the Samin people began to
\end{abstract}


receive formal education. Starting in the 2000s, the majority of the Samin people have taken formal primary and junior high school education. The Samin teachings that are still firmly adhered to as the standard of life for the Samin community are speech, thoughts, and behavior.

Keywords : formal education; standart of life; Samin Society

\section{LATAR BELAKANG}

Pendidikan formal merupakan harapan besar dari orang tua terhadap anak sehingga nantinya akan menjadi orang yang sukses. Makna pendidikan formal bagi setiap individu akan berbeda-beda dengan individu yang lain. Setiap individu memiliki potensi dan keunikan yang berbeda dan baik menurut individu tersebut (Adiwikarta, 2019). Selain itu, makna pendidikan formal yaitu sebagai pondasi awal bagi setiap individu untuk melakukan perubahan yang diinginkan. Perubahan yang baik menjadi keinginan semua orang untuk mendapatkan pendidikan yang baik. Oleh karena itu, bagi orang yang berpendidikan akan memiliki kehidupan yang lebih baik untuk meningkatkan kualitas hidupnya.

Menurut Triyono \& Mufaroh (2018) pendidikan di Indonesia yang semakin membaik akan ada harapan lama sekolah di semua jenjang semakin meningkat. Pendidikan di Indonesia yang semakin baik, namun menurut Bank Dunia bahwa kualitas pendidikan di Indonesia masih rendah. Meskipun, perluasan akses pendidikan untuk masyarakat dianggap sudah meningkat cukup signifikan (Fauzie, 2018). Tingkat kelulusan sekolah di Indonesia pada jenjang SD/sederajat sampai SMA/Sederajat. Kelulusan pada jenjang SD/sederajat yaitu 53,38\%. Terdapat sekitar $24,93 \%$ yang mampu menyelesaikan pendidikan pada jenjang SMP/sederajat. Pada jenjang SM/Sederajat tingkat kelulusan sekolah terdapat Sekitar 21,69\% (Bastari, 2018). Meskipun demikian, masih ada wilayah di Indonesia yang tingkat pendidikannya terbilang cukup rendah.

Salah satu wilayah yang memiliki tingkat pendidikan cukup rendah adalah Kabupaten Blora yang terletak di Provinsi Jawa Tengah. Tingkat pendidikan di Kabupaten Blora masih terbilang rendah, dapat dilihat dari data Susenas Provinsi Jawa Tengah pada tahun 2018 yaitu 3\% lulusan sarjana, sebesar 14\% lulusan SMA, 20\% lulusan SMP, 27\% lulusan SD, dan sisanya 39\% belum tamat SD (BPS, 2018).

Berdasarkan data BPS Kabupaten Blora pada tahun 2018 bidang pendidikan, tingkat kelulusan sekolah masih rendah. Perkembangan zaman yang semakin maju sangat mempengaruhi masyarakat khususnya masyarakat Samin pada bidang pendidikan. Berdasarkan historis, masyarakat Samin yang tidak mau bersekolah formal, saat ini mulai menerima pendidikan formal (Rini, 2015). Masyarakat Samin saat ini mulai bersekolah seperti masyarakat biasa. Masyarakat Samin di Desa Sambongrejo Kecamatan Sambong, mayoritas orang tua Samin telah menempuh pendidikan dasar. Meskipun peningkatan pendidikan masyarakat Samin di Kecamatan Sambong belum terlalu signifikan seperti kecamatan lainnya di Kabupaten Blora. Hal tersebut semakin menarik, karena masyarakat Samin mampu beradaptasi terhadap kemajuan zaman tanpa meninggalkan ajaran yang dimilikinya.

Fokus dari penelitian adalah pada masyarakat Samin di Desa Sambongrejo Kecamatan Sambong Kabupaten Blora. Penelitian ini akan mendeskripsikan sejarah masyarakat Samin di Desa Sambongrejo Kecamatan Sambong Kabupaten Blora. Mendeskripsikan makna pendidikan formal bagi masyarakat Samin di Desa Sambongrejo Kecamatan Sambong Kabupaten Blora. Mendeskripsikan makna ajaran 
Samin dalam perspektif pendidikan formal bagi generasi penerusnya di Desa Sambongrejo Kecamatan Sambong Kabupaten Blora. Berdasarkan latar belakang tersebut penulis tertarik untuk melakukan penelitian dengan judul "Makna Pendidikan Formal dan Ajaran Samin".

Penelitian ini diharapkan dapat memberi informasi, menambah wawasan yang semakin luas, dan pemahaman bagi pembaca. Pengetahuan yang telah diperoleh, sehingga dapat digunakan sebagai referensi untuk peneliti selanjutnya. Manfaat penelitian ini dapat menggambarkan makna pendidikan formal dan pewarisan ajaran Samin bagi masyarakat di Desa Sambongrejo Kecamatan Sambong Kabupaten Blora.

\section{METODE PENELITIAN}

Penelitian ini menggunakan penelitian kualitatif dengan pendekatan deskripstif. Peneliti berperan sebagai instrument utama dalam pengumpulan data. Lokasi yang dijadikan sebagai objek dalam penelitian ini terletak di Desa Sambongrejo Kecamatan Sambong Kabupaten Blora. Teknik pengumpulan data dalam penelitian ini dilakukan melalui tiga cara yaitu observasi, wawancara, dan dokumentasi (Sugiyono, 2015). Observasi yang dilakukan peneliti pada tanggal 31 Oktober 2019 pukul 09.00 WIB kepada Mbah Pram dan Bapak Herman. Wawancara dilakukan pada tanggal 24 Januari 2020 sampai 24 Maret 2020. Wawancara dilakukan dengan informan kunci dan pendukung. Informan kunci dalam penelitian ini adalah sesepuh Samin, remaja Samin yang berusia 13-20 tahun, dan orang tua Samin yang berusia 40-60 tahun. Selain itu terdapat informan pendukung diantaranya koordinator bidang pendidikan \& pengembangan Samin. Adapun teknik analisis data yang digunakan yaitu model interaktif (Miles \& Huberman, 2014) yang terdiri dari pengumpulan data, reduksi data, penyajian data, dan penarikan kesimpulan.

\section{HASIL DAN PEMBAHASAN}

\section{Sejarah Masyarakat Samin di Desa Sambongrejo}

Masyarakat Samin di Desa Sambongrejo dipelopori oleh Siman Surowijoyo sekitar tahun 1890. Siman Surowijoyo merupakan murid dan kaki tangan Samin Surosentiko. Siman Surowijoyo biasanya diberi nama Ki Engkrek yang menyebarkan ajaran Samin ke berbagai daerah. Masyarakat Samin ini hidup berkelompok dalam satu dukuh, sehingga memudahkan mereka untuk berkomunikasi (Mumfangati, 2007; Munawaroh, 2015). Lingkungan sekitar, keluarga khususnya orang tua dan teman sebaya memberikan pengaruh besar bagi masyarakat Samin. Generasi Samin setelah Siman Surowijoyo diwariskan oleh Tarman Turnowijoyo.

Bertambahnya tahun dan zaman, ketua Samin selanjutnya pada tahun 1921 bernama Karmidi Karsodijoyo yang mempunyai pengaruh besar dalam perkembangan pendidikan Samin. Setelah Karmidi meninggal, pada tahun 1977 sampai saat ini ketua Samin berikutnya yaitu Pramugi. Pernyataan tersebut didukung oleh (Rosidin, 2016) generasi tua Samin selalu menasehati generasi penerusnya dalam pembentukan perilaku dan pembiasaan anak. Masyarakat Samin mempunyai sebutan dan pengertian yang berbeda-beda di dalam masyarakat. Pertama, kata yang memiliki pengertian atau bermakna sama atau sami-sami amin. Makna dari sami-sami amin yaitu jika semua setuju dianggap sama sebagai bentuk dukungan rakyat membela negara melawan Belanda. Kedua, nama Samin diketahui sebagai nama tokohnya Samin Surosentiko atau Raden Surowidjojo (nama ketika tua), Raden Surontiko sebagai nama kecil, putra Bupati Tulungagung (Radendra, 2015). 
Masyarakat Samin muncul sebagai perlawanan petani terhadap kebijakan Belanda atas penindasan rakyat kecil yang menimbulkan beberapa dugaan. Menurut Lestari (2008), kemunculan masyarakat melakukan ritual, mistis, dan isolasi diri tersebut sebagai akibat dari merosotnya kewibawaan penguasa pribumi di era penjajahan Belanda. Generasi tua Samin melakukan penolakan membayar pajak karena bukan untuk pribumi. Perlawanan secara ekspresif dengan membuat pasukan (gerombolan dan bramacorah) dan merampok warga pribumi kaya karena mengikuti penjajah untuk kemudian dibagikan pada warga pribumi miskin (Yahya, 2009).

Masyarakat Samin senantiasa berjaga, menorehkan sejarah panjang sejak masa pemerintah Belanda. Masyarakat Samin menyatukan barisan untuk membela negara tanpa senjata api dan hanya bermodalkan senjata sederhana (Munawaroh, 2015). Pada masa kini mereka tidakpun lengah, dengan tetap merekatkan Ajaran-ajaran Samin pada kehidupan sehari-hari. Keindahan hidup dari kearifan dan kesederhaan, bahwa segala ambisi dan egoisme tidak ditemukan pada masyarakat Samin. Hal ini didukung oleh pernyataan Hartanto (2017) masyarakat Samin dari generasi ke generasi, tidak hanya memikirkan tentang keseimbangan alam dan kerukunan hidup antar warga saja. Selain itu juga memikirkan kelangsungan alam untuk generasi penerus dan membantu dalam menjaga keutuhan persatuan nasional.

\section{Makna Pendidikan Formal: Berinteraksi dengan Lingkungan Sekitar}

Pendidikan formal merupakan pendidikan yang diselenggarakan di sekolahsekolah pada umumnya. Jalur pendidikan ini mempunyai jenjang pendidikan yang jelas, mulai dari pendidikan dasar, pendidikan menengah, sampai pendidikan tinggi (Darmadi, 2019). Pendidikan formal bagi masyarakat Samin di Desa sambongrejo merupakan salah satu kewajiban penting untuk membentuk SDM yang berkualitas. Hal ini sesuai dengan yang dijelaskan oleh Triyono \& Mufaroh (2018) bahwa adanya pendidikan formal dapat mengembangkan kemampuan akademis maupun keterampilan lain yang dimiliki seseorang. Pendidikan formal yang dijalankan masyarakat Samin bersama masyarakat sekitar membuat masyarakat Samin mulai terbuka dengan lingkungan diluar Samin. Hal tersebut dibuktikan dengan beberapa tahun terakhir, generasi tua Samin sangat antusias dalam menasehati generasi muda. Sesuai dengan teori stratifikasi sosial oleh Soerjono \& Sulistyowati (2014) tolok ukur keberhasilan peningkatan kualitas seseorang salah satunya dapat dilihat dari cara belajar, hasil belajar, baik pada tingkat dasar maupun lanjutan. Salah satu masalah yang dianggap selalu penting karena merupakan suatu bentuk keberhasilan seseorang dalam belajarnya.

Menempuh pendidikan formal bagi masyarakat Samin, supaya dapat digunakan secara efisien untuk bekal hidupnya. Pendidikan formal yang dijalankan masyarakat Samin sangat mempengaruhi pola pikir masyarakat Samin. Masyarakat Samin yang awalnya tidak mau sekolah formal, setelah menjalankannya membuat masyarakat Samin berkembang menjadi lebih baik lagi (Rini, 2015). Masyarakat Samin yang mulai berbaur dengan masyarakat sekitar saat melakukan pendidikan formal di sekolah. Masyarakat Samin mulai membuka diri dan bertegur sapa dengan lingkungan sekitar. Seiring berjalannya waktu masyarakat Samin dengan lingkungan sekitar menjalin hubungan yang baik. Interaksi sosial berjalan dengan tertib dalam mendorong adanya hubungan timbal balik. Adanya hubungan tibal balik baik antarindividu ataupun antarkelompok dalam sebuah masyarakat (Akbar, 2017). Generasi Samin dalam 
kehidupan sehari-hari, selalu menjalankan pendidikan budi pekerti, sosial, keteladanan sehingga keterpaduan antara teori dan praktik (Rosyid, 2016).

Adanya hubungan interaksi yang baik dengan masyarakat dimulai dari keluarga. Dari keluarga inilah memunculkan suatu pendidikan yang menjadi pedoman utama bagi masyarakat Samin. Pendidikan yang berasal dari keluarga merupakan pendidikan pertama bagi anak, karena seorang anak pertama kali mendapatkan bimbingan (Wahy, 2012). Generasi Samin pertama tahun 1890-an masih dalam pendudukan Belanda yang mempunyai pengaruh besar pendidikan keluarga yaitu Siman Surowijoyo. Menurut Sumarmini (2014) keluarga sebagai sistem sosial terkecil dalam masyarakat yang terdiri dari ayah, ibu, dan anak. Pengetahuan dalam keluarga sebagai peletak dasar-dasar pendidikan dalam pembentukan karakter anak.

Makna ajaran Samin dalam perspektif pendidikan bagi masyarakat Samin merupakan pendidikan karakter bagi generasi penerusnya. Ajaran Samin yang menjadi pedoman hidup bagi masyarakat Samin (Alamsyah, 2015). Perspektif pendidikan bagi masyarakat Samin yaitu rukun, keteladanan, dan kejujuran yang terdapat dalam ajarannya. Pada tahun 1890 terdapat anggota Samin yang bernama Siman Surowijoyo melanjutkan perjuangan Samin Surosentiko.

Makna ajaran Samin merupakan suatu pendidikan yang mengedepankan sikap dan perilaku yang rukun, teladan, dan jujur (Rini, 2015; Rusmawati, 2018). Ketua Samin yang mempunyai peranan penting dalam perkembangan Samin pada tahun 1902 bernama Tarman Turnowijoyo. Makna ajaran Samin dalam perspektif pendidikan dalam hidup masyarakat Samin menjaga kerukunan dengan lingkungan sekitar (Rosyid, 2016). Kerukunan dalam masyarakat Samin yang diterapkan orang tua untuk anak-anaknya harus bisa menjaga bicara dan perilakunya.

Pada tahun 1921 terdapat ketua Samin yang baru bernama Karmidi Karsodijoyo. Karmidi sebagai ketua Samin bersama masyarakat Samin dan lingkungan sekitar memiliki hubungan yang sangat baik meskipun ada perbedaan ajaran yang dianutnya. Masyarakat sekitar Samin yang begitu hangat, membuat suasana tenang dan damai. Masyarakat Samin, dalam memegang teguh ajaran-ajarannya dan tidak berpegang pada kitab tertulis, melainkan ajaran tradisi lisan yang turun temurun (Alamsyah, 2015). Ajaran-ajaran lisan, sangat fasih diucapkan dan dijadikan pedoman bagi masyarakat Samin terutama bagi generasi tua mereka. Ajaran Samin sebagai patokan hidup sebagian besar orang tua Samin mewariskan ajaran Samin sejak usia kecil (Mumfangati, 2007). Secara umum dalam tradisi lisan orang Samin ada ucapan-ucapan yang dianggap ajaran, antara lain agama merupakan senjata hidup (Rusmawati, 2018). Janganlah mengganggu orang, jangan iri hati, jangan suka mengambil barang milik orang lain tanpa seizin pemiliknya.

Makna ajaran Samin dalam perspektif pendidikan dalam hidup masyarakat Samin menjaga kerukunan dengan lingkungan sekitar (Rosyid, 2016). Lingkungan keluarga yang penuh rasa kedamaian, tolong menolong, gotong royong dalam segala hal (Wahy, 2012). Berdasarkan teori interaksi sosial George Simmel, interaksi sesama masyarakat harus baik dengan orang lain. Salah satu nilai kebaikan yang diturunkan dari generasi tua adalah dengan melakukan gotong royong sebagai upaya pembangunan solidaritas (lihat gambar 1). 


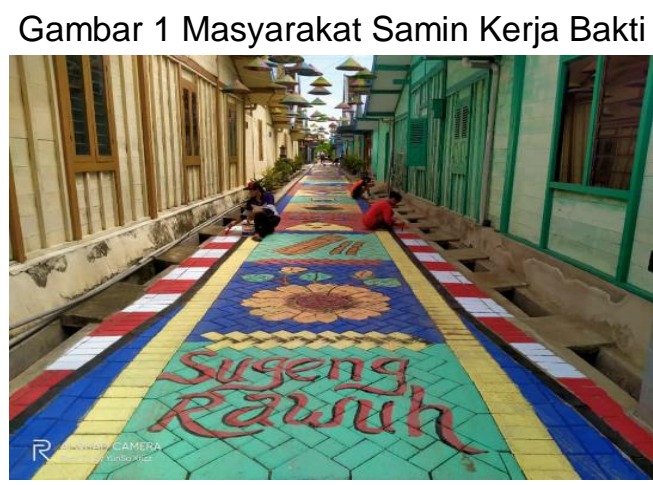

Sumber: (Dokumentasi Penelitian.2020)

Pedoman hidup dari nenek moyang Samin yang diwariskan pada generasi penerus berhubungan dengan aturan-aturan yang ada dalam ajaran Samin yang masih diterapkan hingga saat ini (Munawaroh, 2015). Hal ini tercermin dengan adanya ajaran yang mengatur perilaku masyarakat Samin dalam bentuk ketiga angger-angger. Pertama, angger-angger pengucap (hukum ucapan) maksudnya mengenai ucapan, kalau berbicara harus dijaga. Kedua, angger-angger pertikel (hukum perilaku) maksudnya batin atau pikiran yang menjadi hukum karma. Ketiga, angger-angger lakunana (hukum pelaksanaan) maksudnya kelakuan maksudnya harus bisa menjaga tingkah laku. Jadi jika diartikan secara rinci bahwa semua ucapan, perilaku dan pelaksanaan atau tindakan masyarakat Samin yang diterapkan setiap hari dalam berkehidupan yang dilandaskan nilai kebaikan.

Perkembangan zaman yang semakin maju membuat masyarakat Samin selalu mengingat tujuan hidup yang tidak boleh dilakukan yaitu jrengki, srei, panasten, dahpen, kemeren (Alamsyah, 2015). Tujuan hidup yang pertama jrengki maksudnya jahil, jahat. Kedua, srei maksudnya menyakiti orang lain. Ketiga, panasten maksudnya panas hati. Keempat, dahpen itu ikut campur masalah orang lain. Kelima, kemeren maksudnya iri yang paling kecil. Ajaran Samin selalu diingatkan dan dilaksanakan tanpa mengacuhkan perkembangan zaman saat ini.

\section{Pendidikan sebagai Upaya Mencari Pekerjaan}

Pembentukan karakter dari keluarga membuat anak mempunyai hubungan yang baik dengan orang lain. Selain itu, masyarakat Samin mempunyai pandangan, bahwa makna pendidikan dapat dilakukan sepanjang hayat. Pendidikan sepanjang hayat dalam keluarga adalah pendidikan yang diperoleh setiap anggota keluarga sebagai hasil dari proses belajar (Darmadi, 2019). Proses pembelajaran secara langsung maupun tidak langsung dimana hasilnya dapat berupa pengetahuan, sikap maupun keterampilan yang dapat bertahan selama kehidupannya. Berkembangknya zaman yang semakin maju, membuat masyarakat Samin harus bisa menerima dan mengikutinya (Alamsyah, 2015). Nasihat yang diberikan kedua orang tua membuat generasi penerus Samin mempercayainya. Setiap individu selalu berproses dalam pembelajaran untuk menjadi anak yang sehat, cerdas, kreatif, mandiri, beriman dan lebih baik lagi (Siregar, 2013).

Masyarakat Samin mempunyai pandangan, bahwa pendidikan dapat dilakukan sepanjang hayat. Pendidikan sepanjang hayat yang dilakukan setiap individu dalam masyarakat Samin sehingga saling mempengaruhi. Setiap individu dalam masyarakat harus menyesuaikan dirinya secara terus menerus dengan situasi baru (Whiteford, 2014). 


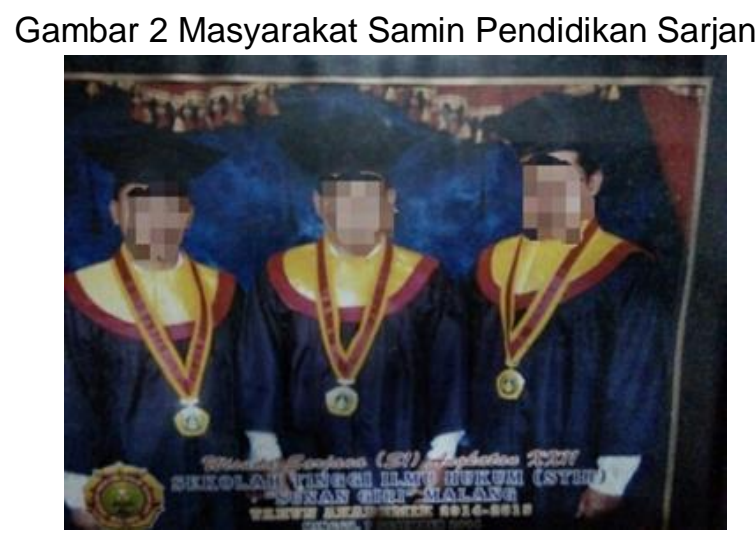

Sumber: (Dokumentasi Penelitian.2020)

Berkembangknya zaman yang semakin maju, membuat masyarakat Samin harus bisa menerima dan mengikutinya. Interaksi sosial yang diungkapkan oleh George Simmel, sebagai interaksi sosial antarindividu, kelompok, dan interaksi sosial kelompok dengan individu. Pembelajaran yang dilakukan masyarakat Samin tidak harus berlangsung di bangku sekolah. Pendidikan masyarakat Samin yang diberikan kedua orang tua dan lingkungan sekitar sehingga dapat memperoleh pembelajaran dan keteladanan.

Makna pendidikan bagi masyarakat Samin sebagai upaya untuk mencari pekerjaan. Masyarakat Samin mulai terbuka dengan masyarakat luar selain Samin dari televisi. Televisi sebagai salah satu media elektronik yang memiliki kekuatan besar dalam memengaruhi masyarakat (Lestari, 2008). Pertama kali masyarakat Samin yang bernama Karmidi mempunyai pandangan pendidikan penting untuk mencari pekerjaan sekitar tahun 1970-an. Masyarakat Samin menyadari dan melakukan sekolah dengan sungguh-sungguh sebagai upaya untuk mendapatkan pekerjaan yang lebih baik (Mumfangati, 2007; Munawaroh, 2015; Yahya, 2009). Adanya media elektronik yaitu televisi membuat masyarakat Samin terbuka pandangannya terhadap pendidikan. Masyarakat Samin mulai berkembang dengan cepat karena adanya telivisi tahun 1970an. Masyarakat Samin berpandangan bahwa menjalankan pendidikan yang tinggi, supaya dikemudian hari akan mendapatkan pekerjaan yang lebih baik (Rosidin, 2016).

Teori interaksi sosial George Simmel, kebutuhan sesama manusia yang dapat menimbulkan interaksi sosial sebagai suatu proses (Akbar, 2017). Adanya interaksi antar masyarakat mengakibatkan masyarakat Samin mengenal masyarakat diluar komunitasnya. Menurut Hartanto (2017) masyarakat Samin saat ini sudah mulai berpikiran maju dan memikirkan masa depannya. Harapan orang tua setelah lulus akan mampu memperoleh pekerjaan yang diinginkan. Selain itu, generasi tua Samin selalu menasehati kepada generasi penerus untuk melanjutkan pendidikan setinggi-tingginya (Mumfangati, 2007; Siregar, 2013) (lihat gambar 2).

\section{Makna Ajaran Samin dalam Perspektif Pendidikan Bagi Generasi Penerus}

Ajaran Samin merupakan pedoman hidup bagi masyarakat Samin. Lahirnya ajaran Samin mendapat sambutan dari rakyat yang kemudian dijadikan wadah kolektif untuk menyalurkan rasa frustasi mereka (Fauzie, 2018). Pada tahun 1890 Samin Surosentiko memperhatikan keadaan masyarakat sekitarnya, hidup dalam kesulitan dan kekurangan yang berkepanjangan. Hal ini didukung oleh pernyataan (Rosidin, 2016) 
Samin Surosentiko yang berkeinginan mendapat petunjuk dari Tuhan dengan jalan bertapa. Samin Surosentiko mendapat wahyu yang berisi bahwa apabila hendak memberikan pertolongan kepada orang-orang yang mengalami kesulitan dan kekurangan hendaknya membentuk suatu perkumpulan.

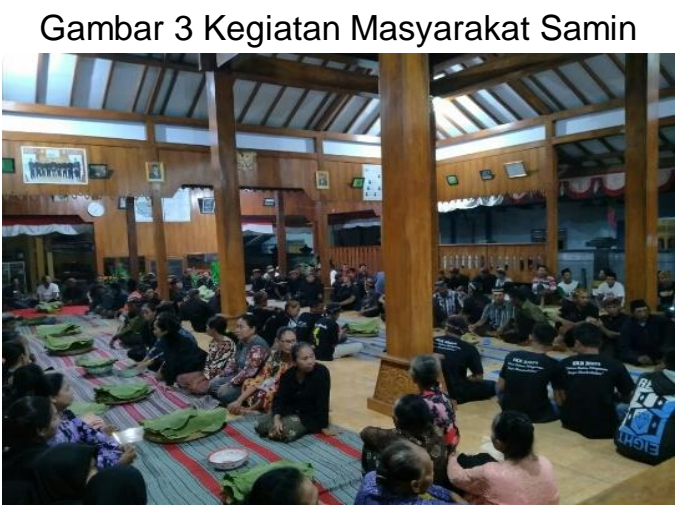

Sumber: (Dokumentasi Penelitian.2020)

Siman Surowijoyo sebagai generasi pertama Samin selalu mewariskan ajaran Samin kepada generasi penerus. Menurut Lestari (2008) generasi tua Samin mengingatkan kepada generasi penerusnya, untuk selalu menjaga dan melaksanakan nilai-nilai religius dimanapun berada. Perkembangan zaman yang semakin maju, membuat penanaman pendidikan religius dari kecil. Pendidikan religius bagi masyarakat Samin yaitu semedi pada Tuhan yang menciptakan alam semesta (Manijo, 2016). Puasa sura selama tujuh hari atau sebulan sesuai kemampuan dan puasa hari lahir dan bersedekah (Radendra, 2015). Melaksanakan ajaran agama tersebut atau tidak sangat tergantung pada pribadi masyarakat Samin. Generasi tua Samin selalu berjuang untuk tetap ada, meskipun banyak orang yang benci Samin (Fauzia, 2019). Masyarakat Samin percaya, bahwa Tuhan selalu mewujudkan apa yang diinginkan melalui keagamaan yang telah dilakukan.

Para sesepuh sebagai orang tua karena setiap orang memiliki jalan yang baik. Ajaran yang diyakini dan diajarkan oleh orang tua pada anak dan cucu masing-masing sesuai dengan keyakinan yang dianut (Fauzia, 2019). Masyarakat Samin pada dasarnya mengacu konsep agama atau ajaran tradisional. Masyarakat Samin percaya, jika terjadi suatu musibah yang datang harus bisa sabar dan menerima dengan lapang dada. Menurut Rusmawati (2018) interaksi sosial untuk membangun hubungan baik dengan orang lain, sangatlah penting. Ketika seseorang bisa menjaga batin dan pikiran, nantinya berdampak baik kepada diri sendiri bahkan berdampak pula terhadap lingkungan sekitar (Lestari, 2008)

Pewariskan ajaran Samin kepada generasi selanjutnya dilakukan secara langsung dengan cara menanamkan ajaran Samin melalui pembelajaran diskusi. Pembelajaran kepada generasi Samin, tentang ajaran yang dianut mempunyai nilai-nilai universal yang mengajarkan kebaikan (Lestari, 2008; Radendra, 2015). Generasi tua mengajarakan ajaran Samin melalui kegiatan diskusi pada tahun 1990-an. Pembelajaran diskusi merupakan salah satu cara yang digunakan masyarakat Samin untuk mencapai tujuan pembelajaran. Menggunakan pembelajaran diskusi dalam 
proses pembelajaran anak, sehingga anak dengan bebas berkomunikasi dalam menggemukakan gagasan dan pendapat masing-masing (Ermi, 2015).

Pewarisan ajaran Samin melalui diskusi antar generasi. Pewarisan ajaran Samin kepada generasi selanjutnya dilakukan secara langsung dengan cara menanamkan ajaran Samin melalui pembelajaran diskusi. Pembelajaran kepada generasi Samin, tentang ajaran yang dianut mempunyai nilai-nilai universal yang mengajarkan kebaikan (Rosidin, 2016). Generasi tua mengajarakan ajaran Samin melalui kegiatan diskusi pada tahun 1990. Menggunakan pembelajaran diskusi dalam proses pembelajaran anak bebas berkomunikasi dalam menggemukakan gagasan dan pendapat (Ermi, 2015).

Masyarakat Samin selalu mengedepankan sikap kebaikan dan kejujuran kepada generasi penerus (Rosyid, 2016). Selain itu, terdapat pula pantangan dalam berperilaku, misalnya dengki, iri, gampang marah, mudah tersinggung, atau membenci sesama (Rini, 2015). Generasi Samin tidak boleh mencuri, kikir, menemukan barang, berbohong, ataupun nasihat buruk. Setiap masyarakat Samin tidak boleh melakukan pantangan, jika melakukan pantangan akan mendapatkan karma. Ajaran samin terus dipelihara dan dikelola untuk terus diinternalisasikan kepada masyarakat (lihat gambar 3).

\section{KESIMPULAN}

Mayoritas generasi muda Samin tidak terlalu paham mengenai sejarah Samin. Sedangkan generasi tua masih berusaha untuk selalu mewariskan dan menjelaskan mengenai sejarah Samin di Desa Sambongrejo. Penyebutan Samin yang terkenal dengan perbuatan negatif seiring berjalannya waktu mulai berubah. Hal tersebut dibuktikan dengan banyaknya masyarakat asing yang berkunjung di lingkungan Samin Desa Sambongrejo. generasi muda Samin yang masih bersekolah umur 14-20 tahun memaknai pendidikan formal supaya masyarakat Samin dapat berinteraksi dengan masyarakat sekitar. Generasi Samin yang menempuh pendidikan formal dapat menambah wawasan yang luas selain dari keluarga. Pembelajaran dari pengalaman generasi tua Samin, lalu kedua orang tua yang dulunya tidak mau sekolah formal. Mayoritas masyarakat Samin saat ini, mempunyai pandangan bahwa pendidikan formal sebagai kewajiban bagi setiap generasi Samin.Makna ajaran Samin dalam perspektif pendidikan bagi generasi penerusnya sebagai patokan hidup masyarakat Samin. Ajaran Samin sebagai patokan hidup masyarakat Samin yaitu ucapan, pikiran, dan tingkah laku. Pendidikan yang diajarakan dari kedua orang tua merupakan pendidikan pertama bagi masyarakat Samin. Pendidikan yang diajarakan dari kedua orang tua merupakan pendidikan utama selain pendidikan formal. Terdapat pula larangan masayarakat Samin yang harus ditepati yaitu jrengki, srei, panasten, dahpen, kemeren. Patokan hidup dan larang hidup masyarakat Samin sampai saat ini yang masih diterapkan dan diwariskan kepada generasi penerusnya. Peneliti selanjutnya diharapkan mengkaji hubungan pendidikan dan interaksi masyarakat sehingga dapat melakukan penelitian mengenai makna pendidikan formal dan ajaran Samin bagi masyarakat di Desa Sambongrejo Kecamatan Sambong Kabupaten Blora.

\section{DAFTAR PUSTAKA}

Adiwikarta, S. (2019). Sosiologi Pendidikan Analisis Sosiologi tentang Praksis Pendidikan. PT Remaja Rosdakarya.

Akbar, D. (2017). Keluarga Bahagia Sembilan Memoar Luka Keluarga Indonesia. Radio 
Buku.

Alamsyah. (2015). Eksistensi dan Nilai-Nilai Kearifan Komunitas Samin di Kudus dan Pati. Jurnal Humanika, 21(1), 63-74. https://doi.org/10.14710/humanika.21.1.63-74

Bastari. (2018). Indonesia Educational Statistics In Brief. Kementerian Pendidikan dan Kebudayaan.

BPS. (2018). Indikator Utama Sosial, Politik dan Keamanan Provinsi Jawa Tengah. Badan Pusat Statistik.

Darmadi, H. (2019). Pengantar Pendidikan Era Global Konsep Dasar Teori, Strategi dan Implementasi dalam Pendidikan Globalisasi. An1mage.

Ermi, N. (2015). Penggunaan Metode Diskusi untuk Meningkatkan Hasil Belajar Materi Perubahan Sosial pada Siswa Kelas XII SMA Negeri 4 Pekanbaru. Jurnal Sorot, 10(2), 155-168. http://dx.doi.org/10.31258/sorot.10.2.155-168

Fauzia, A. (2019). Arti Memelihara Tradisi Pada Suku Samin Interpretative Phenomenological Analysis. Jurnal Empati, 8(1), 228-237.

Fauzie, Y. Y. (2018). Bank Dunia: Kualitas Pendidikan Indonesia Masih Rendah. Cnnindonesia. https://www.cnnindonesia.com/gaya-hidup/20180607113429-284304214/bank-dunia-kualitas-pendidikan-indonesia-masih-rendah

Hartanto, D. A. (2017). Local Wisdom of Sedulur Sikep (Samin) Society's Marriage in Kudus: Perspective of Law Number 1 Year 1974 on Marriage. Jurnal Dinamika Hukum, 17(2), 133-138. http://dx.doi.org/10.20884/1.jdh.2017.17.2.723

Lestari, P. (2008). Analisis Perubahan Sosial pada Masyarakat Samin (Studi Kasus di Desa Mendenrejo, Kecamatan Kradenan, Blora. Jurnal Dimensia, 2(2), 20-31. http://dx.doi.org/10.21831/dimensia.v2i2.3403

Manijo. (2016). Dinamika Sedulur Sikep Kaliyoso: Geneologi Gerakan Dan Diskursus Pendidikan. Jurnal Penelitian Pendidikan Islam, 11(1), 51-68. http://dx.doi.org/10.21043/edukasia.v11i1.804

Miles, M., \& Huberman, A. (2014). Analisis Data Kualitatif. UI-Press.

Mumfangati, D. (2007). Kearifan Lokal di Lingkungan Masyarakat Samin Kabupaten Blora Jawa Tengah. Kantor Pariwisata dan Kebudayaan Kabupaten Blora.

Munawaroh, D. (2015). Etnografi Masyarakat Samin di Bojonegoro: Potret Masyarakat Samin dalam Memaknai Hidup Pelestarian Nilai Budaya. Balai Pelestarian Nilai Budaya.

Radendra. (2015). Manifestasi Ajaran Samin pada Kehidupan Penganutnya: Studi Kualitatif Fenomenologi pada Penganut Ajaran Samin di Blora. Jurnal Empati, 4(4), 118-123.

Rini, R. (2015). Pendidikan Formal dalam Perspektif Sedulur Sikep (Studi Kasus pada Sedulur Sikep Desa Klopoduwur Kabupaten Blora). Jurnal Solidarity, 4(2), 71-81. https://journal.unnes.ac.id/sju/index.php/solidarity/issue/view/687

Rosidin. (2016). Role of Local Wisdom in Preserving The Religious Harmony of Samin Community in Blimbing Blora. International Journal of Latest Recearch in Science and Technology, 2(2), 25-30.

Rosyid. (2016). Upaya Komunitas Samin di Kudus Jawa Tengah dalam Mempertahankan Jati Diri di Tengah Problematika Kehidupannya. Jurnal IImu-IImu Sosial Indonesia, 42(2), 167-184. https://doi.org/10.14203/jmi.v42i2.670

Rusmawati. (2018). Makna Spiritualitas pada Penganut Samin. Jurnal Empati, 7(3), 164-173.

Siregar, N. (2013). Persepsi Orang Tua terhadap Pentingnya Pendidikan bagi Anak. Jurnal IImu Pemerintahan Dan Sosial Politik, 1(1), 11-27. https://doi.org/10.31289/jppuma.v1i1.548

Sugiyono. (2015). Metode Penelitian Kuantitatif, Kualitatif dan R\&D. Alfabeta.

Wahy, H. (2012). Keluarga Sebagai Basis Pendidikan Pertama Dan Utama. Jurnal IImiah Didaktika, 12(2), 245-258. http://dx.doi.org/10.22373/jid.v12i2.451

Whiteford, P. (2014). Global Education First and Educate a Child: a Comparative Analysis. Policy Futures in Education, 12(6), 748-752. 
https://doi.org/10.2304\%2Fpfie.2014.12.6.748

Yahya, I. (2009). Identitas Kearifan Lokal “Islam Samin” di Era Global. Jurnal Millah, 8(2), 209-223. https://doi.org/10.20885/millah.vol8.iss2.art1 